\title{
1 An improved MS2-MCP imaging system with minimal perturbation of mRNA \\ 2 stability
}

4 Weihan Li ${ }^{1,2, \#, ~ A n n a ~ M a e k i n i e m i ~ 1,2, \#, ~ H a n a e ~ S a t o ~}{ }^{1,2}$, Christof Osman ${ }^{3}$, and

5 Robert H. Singer $1,2, *$

6

$7 \quad{ }^{1}$ Program in RNA Biology, Albert Einstein College of Medicine, Bronx, NY, 10461, USA

$8{ }^{2}$ Department of Cell Biology, Albert Einstein College of Medicine, Bronx, NY, 10461, USA

$9{ }^{3}$ Faculty of Biology, Ludwig-Maximilians-Universität München, 82152 Planegg-Martinsried,

10 Germany.

11 \# These authors contribute equally to this work

12 * Correspondence: Robert H. Singer (robert.singer@einsteinmed.edu)

13 


\section{Abstract:}

16 The MS2-MCP imaging system is widely used to study the mRNA spatial

17 distribution in living cells. Here, we report that the MS2-MCP system may

18 destabilize the tagged mRNA by targeting it to the nonsense-mediated mRNA

19 decay pathway. We introduce an improved version, which has minimal

20 perturbation of the mRNA stability.

\section{Main:}

24 The spatial distribution of mRNA regulates its gene expression ${ }^{1}$. The MS2-MCP

25 system is widely used to image mRNAs with high spatial-temporal resolution in

26 living cells ${ }^{1,2}$. Specifically, an mRNA of interest is genetically fused to an array of

27 MS2 binding sites (MBS) in its 3' UTR. Fluorescently labeled MS2-coat proteins

28 (MCP) bind to the MBS array, making the mRNA molecules appear as diffraction-

29 limited spots under wide-field epifluorescence microscopy ${ }^{3}$. Capturing the mRNAs'

30 innate behavior requires minimum perturbation from the imaging system. Recent

31 advances in the design of the MBS array improved its imaging accuracy by

32 avoiding the aggregation of decay-resistant fragments ${ }^{3}$. In this study, we report

33 that the MS2-MCP system may destabilize the tagged transcript through

34 nonsense-mediated mRNA decay (NMD). We present an improved MS2-MCP

35 system that minimizes the mRNA destabilization. 
37 The length of 3' UTR regulates mRNA stability. Long 3' UTRs cause aberrant 38 translation termination and render the mRNA degraded through $\mathrm{NMD}^{4,5}$, which is

39 a quality control pathway that degrades mRNAs with premature stop codons, long

40 3' UTRs, or upstream open reading frames (uORFs) ${ }^{6}$. The median length of yeast

41 3' UTRs is $104 \mathrm{nt}^{7}$, whereas a $24 \times \mathrm{xMB}$ array is $1,660 \mathrm{nt}$. Thus, MBS tagging in

42 yeast extends 3' UTRs by 16-fold on average and, as a result, could render the

43 mRNA a target of NMD. To explore this notion, we genetically fused the MBS array

44 to the 3' UTRs of eight yeast genes and examined their steady-state mRNA levels

45 using qPCR. Three of the genes, ATP2, HAC1, and PMA1, had different degrees

46 of mRNA reduction when tagged with the MBS array (Figure 1A). In contrast, the

47 mRNA levels of the remaining five genes, including $A C T 1$, were not significantly

48 affected by the MBS tagging (Figure 1A, Supplementary Figure 1A-C) (see

49 Discussion). ATP2 encodes the $ß$ subunit of $F_{1}-A T P$ synthase ${ }^{8}$. Using $q P C R$ and

50 single-molecule RNA fluorescent in situ hybridization (smFISH), we found that the

51 level of the ATP2 mRNA reduced to $30 \%$ after MBS tagging, representing the

52 largest mRNA reduction among the genes we tested (Figure 1B-D). The effect of

53 mRNA destabilization did not change when the MBS array was inserted at a

54 different location in the 3' UTR, the number of MBS repeats was reduced from 24

55 to 12, or the binding protein MCP-GFP was co-expressed (Figure 1B,

56 Supplementary Figure 2). The destabilization of ATP2 mRNA exhibited a

57 phenotypic impact as the yeast cells with the MBS-tagged ATP2 grew slower on a

58 non-fermentable carbon source (Figure 1E). This is consistent with ATP2's role in

59 oxidative phosphorylation. HAC1 encodes the transcription factor regulating 
60 protein folding homeostasis in the endoplasmic reticulum $(E R)^{9}$. The level of the

61 HAC1 mRNA reduced to $50 \%$ after MBS tagging, thereby decreasing the cellular

62 fitness under ER protein folding stress conditions (Figure 1A and F). To test

63 whether the NMD pathway was responsible for destabilizing the MBS-tagged

64 mRNAs, we deleted UPF1, a core mediator of $\mathrm{NMD}^{10}$. Deletion of UPF1 recovered

65 the levels of the tagged mRNAs (Figure 1A) and the growth phenotypes (Figure

66 1E and F). Hence, tagging with an MBS array may destabilize yeast mRNAs

67 through NMD.

69 Next, we sought to modify the MS2-MCP system to minimize the destabilization

70 effect. Previous studies showed that long 3' UTRs in yeast cause inefficient

71 translation termination and subsequently trigger $\mathrm{NMD}^{4}$. Tethering the yeast

72 translation termination factor, SUP35, or Poly $(A)$ binding protein, PAB1, to the

73 vicinity of the stop codon increased the efficiency of translation termination,

74 thereby protecting the mRNA from $\mathrm{NMD}^{4,11}$. Inspired by these studies, we

75 expressed the fusion protein MCP-GFP-SUP35 or MCP-GFP-PAB1, which should

76 bind to the MBS-tagged mRNA, making the mRNA fluorescent through GFP and

77 correcting the mRNA stability through SUP35 or PAB1 (Figure 2A). When using

78 MCP-GFP-PAB1, we noticed that the MBS-tagged mRNAs were not detected

79 using fluorescent microscopy (Supplementary Figure 3A). We surmised that the

80 MCP-GFP-PAB1 bound to the poly $(A)$ tails of other mRNAs through the PAB1

81 RNA-binding domain. To test this idea, we used PAB1(F170V, F366V) (referred to

82 as $\mathrm{PAB1}^{*}$ in this study), which is a mutant that harbors two point mutations at 
83 conserved residues of its RNA-binding domain (Supplementary Figure 3B, C). The

84 RNA binding affinity of PAB1* is nearly 1,000-fold lower than that of the wild-type

$85(\mathrm{WT})^{12}$. As a result, the MCP-GFP-PAB1* is expected to have higher specificity for

86 the MBS arrays. Indeed, MBS-tagged mRNAs became visible when using MCP-

87 GFP-PAB1* (Supplementary Figure 3A). Expressing the fusion protein MCP-GFP-

88 SUP35 or MCP-GFP-PAB1* recovered the steady-state levels of the MBS-tagged

89 ATP2, HAC1, and PMA1 mRNAs, as well as their corresponding growth

90 phenotypes (Figure 2B-D). ACT1 represents the mRNAs that were not destabilized

91 by the MBS tagging. The MCP fusion proteins didn't change the level of the tagged

92 ACT1 mRNA (Supplementary Figure 4). Therefore, these data showed that the

93 MCP-GFP-SUP35 and MCP-GFP-PAB1* can be used to image mRNAs with

94 minimal perturbation of mRNA stability.

96 We tested whether the improved MS2-MCP system could faithfully report on

97 mRNA distribution. Previous studies showed that the ATP2 mRNA is translated at

98 mitochondrial periphery, thereby promoting the import of the nascent ATP2

99 proteins $^{13}$. In fixed cells, we imaged ATP2 mRNAs using smFISH, and

100 mitochondria using a mitochondrial-targeted fluorescent protein. About half of the

101 ATP2 mRNAs co-localized with mitochondria in WT cells, as well as in cells

102 expressing the improved MS2-MCP system (Figure 2E and F). This result

103 suggested that the improved MS2-MCP system did not perturb the mRNA

104 localization. In living cells, we imaged ATP2 mRNAs using the MCP-GFP-SUP35

105 and showed that ATP2 mRNAs moved in trajectories that coincide with the 
106 mitochondrial network (Supplementary Figure 5, Supplementary Movie 1 and 2).

107 Therefore, the improved MS2-MCP system faithfully reported on the mRNA

108 distribution.

109

110 To extend our study to mammalian cells, we examined the ß-actin mRNA in

111 mouse embryonic fibroblasts (MEFs) and P21 mRNAs in U2OS cell lines because

112 they have been tagged with the MBS arrays in previous studies ${ }^{14,15}$. MBS tagging

113 reduced the $P 21$ mRNA level but did not change the $ß$-actin mRNA level (Figure

$1142 \mathrm{G})$. This is similar to what we observed in yeast as the MBS-induced

115 destabilization varied from gene to gene. When UPF1 was knocked down using

116 shRNA, the level of the tagged $P 21$ mRNA recovered, suggesting that the mRNA

117 destabilization occurred through the NMD pathway (Figure 2G, H). To minimize

118 the destabilization, MCP-GFP was genetically fused to eRF3 or PABPC1(F142V,

119 F337V) (referred to as PABPC1* in this study), which are the mammalian

120 homologs of SUP35 and PAB1*. Expressing the MCP-GFP-eRF3 fully restored the

121 level of the $P 21 \mathrm{mRNA}$, showing the fusion protein's conserved function in yeast

122 and mammalian cells. On the other hand, expressing the MCP-GFP-PABPC1*

123 moderately restored the mRNA level (Figure $2 \mathrm{G}$ ). The degree of mRNA recovery

124 increased as the expression level of the MCP-GFP-PABPC1* increased

125 (Supplementary Figure 6). Therefore, MCP-GFP-eRF3 could better restore the

126 stability of the MBS-tagged P21 mRNA in mammalian cells. 
128 In summary, we reported that the MBS tagging may decrease the mRNA

129 stability by targeting the transcripts to the NMD pathway. We presented an

130 improved MS2-MCP system, in which MCP-GFP-SUP35/eRF3 or MCP-GFP-

$131 \mathrm{PAB1}^{*} / \mathrm{PABPC}^{*}$ protected the tagged yeast/mammalian mRNAs from NMD.

132 Orthogonal RNA imaging methods, including the PP7-PCP system or aptamer-

133 based RNA imaging methods, achieve single-molecule resolution using a similar

134 strategy of repeated tags ${ }^{16}$. These tags increase the length of the $3^{\prime}$ UTR and may

135 analogously destabilize the mRNA. Our improved MS2-MCP system provides a

136 template to antagonize NMD and correct the mRNA stability. In this study, we

137 observed that the MBS-induced NMD varied from gene to gene even though the

138 tagged mRNAs had similar 3' UTR lengths. This resembles the situation in

139 mammalian cells where NMD may differentially regulate endogenous mRNAs with

140 comparable 3' UTR lengths. The differential regulation by NMD may be determined

141 by additional factors, including cis-elements in the $3^{\prime}$ UTR, proteins bound to the

$142 \mathrm{mRNA}$, and the translation readthrough rate ${ }^{17-21}$. We recommend to assess the

143 effect of MBS tagging on an mRNA of interest before choosing the MS2-coat

144 protein construct. If MBS tagging does not change the mRNA stability, one can

145 use the original MCP-GFP. In contrast, if MBS tagging reduces the mRNA stability,

146 we recommend the MCP-GFP-SUP35/eRF3 or MCP-GFP-PAB1*/PABPC1*.

147 Altogether, the new MS2-MCP system has minimized impact on mRNA stability

148 and can faithfully report on the mRNA's spatial distributions in living cells. We

149 believe it will see widespread applications in future studies. 
bioRxiv preprint doi: https://doi.org/10.1101/2022.02.05.479257: this version posted February 6, 2022. The copyright holder for this preprint

(which was not certified by peer review) is the author/funder, who has granted bioRxiv a license to display the preprint in perpetuity. It is made available under aCC-BY-NC-ND 4.0 International license.

\section{Acknowledgements:}

151 We thank Allan Jacobson, U. Thomas Meier, Robert A. Coleman, and members

152 of the Singer lab for their insightful discussions. This work was supported by

153 American Heart Association Postdoctoral Fellowship \#903024 (WL), 1R35

154 GM136296-01 (RHS), and the European Research Council ERCStG-714739

155 IlluMitoDNA (CO).

156 


\section{Figure 1. MBS tagging may destabilize mRNA through the NMD pathway in}

158 yeast. (A) qPCR of the MBS-tagged mRNAs in WT (W) or $\Delta$ upf1 ( $\Delta$ ) strain

159 backgrounds. The mRNA levels were normalized to their corresponding WT

160 mRNAs. (B) qPCR of the ATP2 mRNAs tagged with $24 x$ or $12 x$ MBS array in the

161 presence or absence of MCP-GFP. (C) Representative images of ATP2 mRNA

162 smFISH (green). Mitochondria were labeled using mitochondrial-targeted

163 fluorescent protein (red). Images were max-Z projected. Scale bars are $2 \mu \mathrm{m}$. (D)

164 The number of ATP2 mRNAs per cell as quantified from the smFISH images. (E,

165 F) Cell growth assay on plates with the indicated carbon source (E) or the ER

166 stress inducer tunicamycin $(F)$. 


\section{Figure 2. The improved MS2-MCP system minimizes the mRNA}

169 destabilization in yeast and mammalian cells. (A) Cartoon illustration of the

170 improved MS2-MCP system. (B) qPCR of the indicated mRNAs. The mRNA levels

171 were normalized to their corresponding WT mRNAs. (C, D) Cell growth assay with

172 the same conditions as in Figure $1 \mathrm{E}$ and $\mathrm{F}$. (E) smFISH of ATP2 mRNAs. The

173 experimental setups and scale bars are the same as in Figure 1C. (F) Quantifying

174 the proportion of the mitochondria-localized ATP2 mRNAs from the smFISH

175 images. (G) qPCR of the MBS-tagged $P 21$ mRNA in U2OS cells and $ß$-actin mRNA

176 in MEFs. The mRNA levels were normalized to their corresponding WT mRNAs.

177 Error bars were calculated from qPCR replicates. $(\mathrm{H})$ qPCR of UPF1 mRNA in the 178 presence or absence of the UPF1 shRNA. 
180 Supplementary Figure 1. MBS tagging does not destabilize all mRNAs. (A)

181 qPCR of untagged and MBS-tagged mRNAs. The mRNA levels were normalized

182 to their corresponding WT mRNAs. (B) Representative images of CLB2 mRNA

$183 \mathrm{smFISH}$ (green). DNA was stained with DAPI (blue). Scale bars are $2 \mu \mathrm{m}$. (C) The

184 number of CLB2 mRNAs per cell quantified from smFISH images. 


\section{Supplementary Figure 2. The steady-state levels of the ATP2 mRNA}

187 remained the same after altering the location where the MBS array was

188 inserted. (A) Illustration of the tagging positions. Position 1 is immediately

189 downstream of the stop codon, while position 2 is $162 \mathrm{nt}$ downstream of the stop

190 codon. (B) qPCR of the indicated ATP2 mRNAs. 


\section{Supplementary Figure 3. MCP-GFP-PAB1* can be used to image the MBS-}

193 tagged ATP2 mRNAs. (A) Live-cell imaging of yeast cells expressing MCP-GFP-

194 PAB1 (left) or MCP-GFP-PAB1* (right). Images were max-Z projected. Scale bars

195 are $2 \mu \mathrm{m}$. Cell outline is marked with white dashed line. (B, C) Sequence alignment

196 of the PAB1 homologs flanking the two conserved phenylalanines, which are the

$197 \mathrm{~F} 170$ and F366 in the yeast PAB1 (F142 and F337 in the human PABPC1). These

198 two phenylalanines were mutated to valines in PAB1*/PABPC1*. 


\section{Supplementary Figure 4. Expressing MCP-GFP-SUP35 or MCP-GFP-PAB1*}

201 did not change the steady-state level of the MBS-tagged ACT1 mRNA. The

202 indicated ACT1 mRNAs were measured by qPCR. 


\section{Supplementary Figure 5. Tracking single-molecule ATP2 mRNAs using the}

205 improved MS2-MCP system. The original movie is shown in Supplementary

206 Movie 1. Mitochondria were labeled using a mitochondria-targeted mKate2. MBS-

207 tagged ATP2 mRNAs were imaged with MCP-GFP-SUP35. The movie was

208 acquired at 20 frames per second in one $z$ plane. The figure shows the molecular

209 trajectories of the mRNAs that were tracked for at least 40 consecutive frames

210 (white arrowed lines). Mitochondria are in red. Cell outline is marked with white

211 dashed line. Scale bar is $2 \mu \mathrm{m}$ 
212 Supplementary Figure 6 . The $P 21$ mRNA recovery increased as the

213 expression level of the MCP-GFP-PABPC1* increased. Cells were sorted by

214 FACS based on the expression level of MCP-GFP-PABPC1*. The level of the $P 21$

215 mRNA was examined by qPCR. Error bars were calculated from qPCR replicates. 


\section{Supplementary Movie 1. Live-cell imaging of ATP2 mRNAs using MCP-GFP-}

219 SUP35. Mitochondria (red) were labeled using a mitochondria-targeted mKate2.

220 MBS-tagged ATP2 mRNAs (green) were imaged with MCP-GFP-SUP35. The

221 movie was acquired at 20 frames per second in one $z$ plane. Scale bar is $2 \mu \mathrm{m}$. 
bioRxiv preprint doi: https://doi.org/10.1101/2022.02.05.479257; this version posted February 6, 2022. The copyright holder for this preprint (which was not certified by peer review) is the author/funder, who has granted bioRxiv a license to display the preprint in perpetuity. It is made available under aCC-BY-NC-ND 4.0 International license.

223 Supplementary Movie 2. Live-cell imaging of ATP2 mRNAs using MCP-GFP-

224 SUP35. Experimental setup is the same as Supplementary Movie 1. Scale bar is

$2252 \mu \mathrm{m}$.

226 


\begin{tabular}{|c|c|c|}
\hline $\begin{array}{l}227 \\
228 \\
229\end{array}$ & & ces: \\
\hline $\begin{array}{l}30 \\
31 \\
32\end{array}$ & 1 & $\begin{array}{l}\text { Tutucci, E., Livingston, N. M., Singer, R. H. \& Wu, B. Imaging mRNA In } \\
\text { Vivo, from Birth to Death. Annu Rev Biophys 47, 85-106, } \\
\text { doi:10.1146/annurev-biophys-070317-033037 (2018). }\end{array}$ \\
\hline 34 & 2 & $\begin{array}{l}\text { Biswas, J., Li, W., Singer, R. H. \& Coleman, R. A. Imaging Organization of } \\
\text { RNA Processing within the Nucleus. Cold Spring Harb Perspect Biol 13, } \\
\text { doi:10.1101/cshperspect.a039453 (2021). }\end{array}$ \\
\hline & 3 & $\begin{array}{l}\text { Tutucci, E. et al. An improved MS2 system for accurate reporting of the } \\
\text { mRNA life cycle. Nat Methods 15, 81-89, doi:10.1038/nmeth.4502 (2018). }\end{array}$ \\
\hline $\begin{array}{l}39 \\
40\end{array}$ & 4 & $\begin{array}{l}\text { Amrani, N. et al. A faux } 3 \text { '-UTR promotes aberrant termination and triggers } \\
\text { nonsense-mediated mRNA decay. Nature 432, 112-118, } \\
\text { doi:10.1038/nature03060 (2004). }\end{array}$ \\
\hline $\begin{array}{l}41 \\
42 \\
43\end{array}$ & 5 & $\begin{array}{l}\text { Kebaara, B. W. \& Atkin, A. L. Long 3'-UTRs target wild-type mRNAs for } \\
\text { nonsense-mediated mRNA decay in Saccharomyces cerevisiae. Nucleic } \\
\text { Acids Res } 37,2771-2778 \text {, doi:10.1093/nar/gkp146 (2009). }\end{array}$ \\
\hline $\begin{array}{l}44 \\
45\end{array}$ & 6 & $\begin{array}{l}\text { Kurosaki, T., Popp, M. W. \& Maquat, L. E. Quality and quantity control of } \\
\text { gene expression by nonsense-mediated mRNA decay. Nat Rev Mol Cell } \\
\text { Biol 20, 406-420, doi:10.1038/s41580-019-0126-2 (2019). }\end{array}$ \\
\hline $\begin{array}{l}47 \\
48 \\
49\end{array}$ & 7 & $\begin{array}{l}\text { Nagalakshmi, U. et al. The transcriptional landscape of the yeast genome } \\
\text { defined by RNA sequencing. Science } 320,1344-1349 \text {, } \\
\text { doi:10.1126/science.1158441 (2008). }\end{array}$ \\
\hline $\begin{array}{l}50 \\
51 \\
52\end{array}$ & 8 & $\begin{array}{l}\text { Takeda, M., Vassarotti, A. \& Douglas, M. G. Nuclear genes coding the } \\
\text { yeast mitochondrial adenosine triphosphatase complex. Primary sequence } \\
\text { analysis of ATP2 encoding the F1-ATPase beta-subunit precursor. J Biol } \\
\text { Chem 260, 15458-15465 (1985). }\end{array}$ \\
\hline $\begin{array}{l}254 \\
255 \\
256\end{array}$ & 9 & $\begin{array}{l}\text { Cox, J. S. \& Walter, P. A novel mechanism for regulating activity of a } \\
\text { transcription factor that controls the unfolded protein response. Cell } 87 \text {, } \\
391-404 \text {, doi:10.1016/s0092-8674(00)81360-4 (1996). }\end{array}$ \\
\hline $\begin{array}{l}257 \\
258 \\
259\end{array}$ & 10 & $\begin{array}{l}\text { Kim, Y. K. \& Maquat, L. E. UPFront and center in RNA decay: UPF1 in } \\
\text { nonsense-mediated mRNA decay and beyond. RNA 25, 407-422, } \\
\text { doi:10.1261/rna.070136.118 (2019). }\end{array}$ \\
\hline $\begin{array}{l}260 \\
261 \\
262\end{array}$ & 11 & $\begin{array}{l}\text { Kervestin, S., Li, C., Buckingham, R. \& Jacobson, A. Testing the faux-UTR } \\
\text { model for NMD: analysis of Upf1p and Pab1p competition for binding to } \\
\text { eRF3/Sup35p. Biochimie 94, 1560-1571, doi:10.1016/j.biochi.2011.12.021 } \\
\text { (2012). }\end{array}$ \\
\hline $\begin{array}{l}264 \\
265 \\
266\end{array}$ & 12 & $\begin{array}{l}\text { Deardorff, J. A. \& Sachs, A. B. Differential effects of aromatic and charged } \\
\text { residue substitutions in the RNA binding domains of the yeast poly(A)- } \\
\text { binding protein. J Mol Biol 269, 67-81, doi:10.1006/jmbi.1997.1013 (1997). }\end{array}$ \\
\hline $\begin{array}{l}267 \\
268 \\
269\end{array}$ & 13 & $\begin{array}{l}\text { Margeot, A. et al. In Saccharomyces cerevisiae, ATP2 mRNA sorting to } \\
\text { the vicinity of mitochondria is essential for respiratory function. EMBO J } \\
21,6893-6904 \text {, doi:10.1093/emboj/cdf690 (2002). }\end{array}$ \\
\hline $\begin{array}{l}270 \\
271\end{array}$ & 14 & $\begin{array}{l}\text { Lionnet, T. et al. A transgenic mouse for in vivo detection of endogenous } \\
\text { labeled mRNA. Nat Methods 8, 165-170, doi:10.1038/nmeth.1551 (2011). }\end{array}$ \\
\hline
\end{tabular}


27215 Carvajal, L. A. et al. Dual inhibition of MDMX and MDM2 as a therapeutic

273

274

275

276

277

278

279

280

281

282

283

284

285

286

287

288

289

290

291

292

293 strategy in leukemia. Sci Transl Med 10, doi:10.1126/scitranslmed.aao3003 (2018).

16 Braselmann, E., Rathbun, C., Richards, E. M. \& Palmer, A. E. Illuminating RNA Biology: Tools for Imaging RNA in Live Mammalian Cells. Cell Chem Biol 27, 891-903, doi:10.1016/j.chembiol.2020.06.010 (2020).

17 Ruiz-Echevarria, M. J. \& Peltz, S. W. The RNA binding protein Pub1 modulates the stability of transcripts containing upstream open reading frames. Cell 101, 741-751, doi:10.1016/s0092-8674(00)80886-7 (2000).

18 Ge, Z., Quek, B. L., Beemon, K. L. \& Hogg, J. R. Polypyrimidine tract binding protein 1 protects mRNAs from recognition by the nonsensemediated mRNA decay pathway. Elife 5, doi:10.7554/eLife.11155 (2016).

19 Annibaldis, G. et al. Readthrough of stop codons under limiting ABCE1 concentration involves frameshifting and inhibits nonsense-mediated mRNA decay. Nucleic Acids Res 48, 10259-10279, doi:10.1093/nar/gkaa758 (2020).

20 Hogg, J. R. \& Goff, S. P. Upf1 senses 3'UTR length to potentiate mRNA decay. Cell 143, 379-389, doi:10.1016/j.cell.2010.10.005 (2010).

21 Kurosaki, T. \& Maquat, L. E. Rules that govern UPF1 binding to mRNA 3' UTRs. Proc Natl Acad Sci U S A 110, 3357-3362, doi:10.1073/pnas.1219908110 (2013). 
bioRxiv preprint doi: $\mathrm{https} / /$ doi.org/10.1101/2022.02 05.479257; this version posted February 6, 2022. The copyright holder for this preprint (which was not certified by peer review) is the author/funder, who has granted bioRxiv a license to display the preprint in perpetuity. It is made available under aCC-BY-NC-ND 4.0 International license.

Figure $1 \quad$ Li \& Maekiniemi et al

A

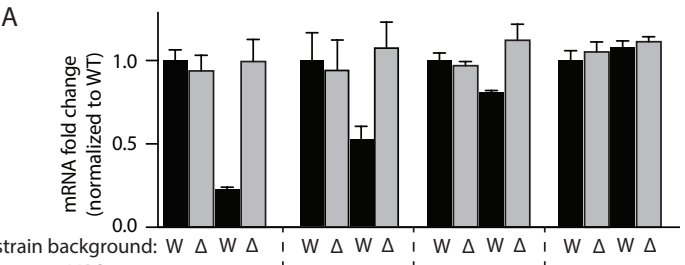

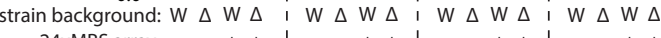

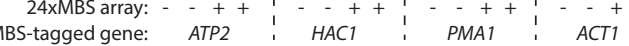

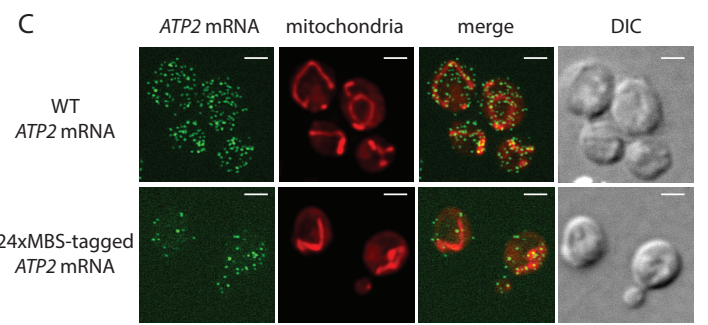

B
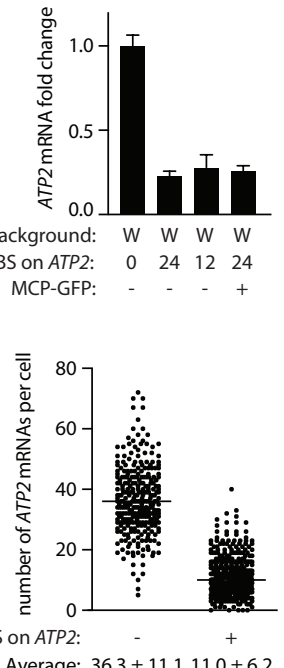

E strain background: WT $\Delta a t p 2$ WT WT WT $\Delta$ upf1 $\Delta$ upf1 WT $\Delta a t p 2$ WT WT WT $\Delta$ upf1 1 upf1 \# of MBS on ATP2: $00 \begin{array}{lllllllllllll}0 & 24 & 12 & 24 & 24 & 0 & 0 & 0 & 24 & 12 & 24 & 24 & 0\end{array}$ MCP-GFP:

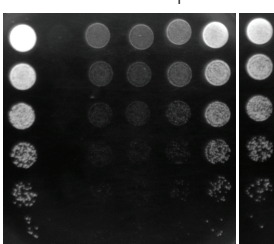

glycerol

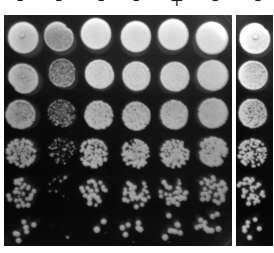

glucose

F strain background: WT $\Delta$ hac1 WT $\Delta$ upf1 $\Delta$ upf1 WT $\Delta$ hac1 WT $\Delta$ upf1 1 upf1 \# of MBS on HAC1: $0 \begin{array}{llllllllll}0 & 0 & 24 & 24 & 0 & 0 & 0 & 24 & 24 & 0\end{array}$
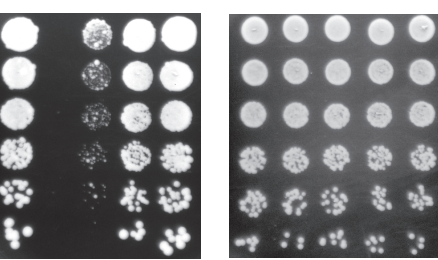

Tunicamycin: 
bioRxiv preprint doi: https://doi.org/10.1101/2022.02.05.479257; this version posted February 6, 2022. The copyright holder for this preprint (which was not certified by peer review) is the author/funder, who has granted bioRxiv a license to display the preprint in perpetuity. It is made available under aCC-BY-NC-ND 4.0 International license.

Figure 2 Li \& Maekiniemi et al

A

MCP-GFP-SUP35/eRF3 or MCP-GFP-PAB $1 * /$ PABPC $1 *$ *

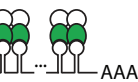

C

strain background: WT WT WT WT WT WT \# of MBS on ATP2: $\quad 0 \quad 12 \quad 12 \quad 24 \quad 12 \quad 24$ MCP-GFP: MCP-GFP-SUP35: MCP-GFP-PAB1*

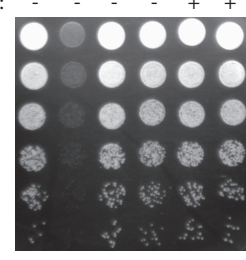

carbon:

glycerol

E

ATP2 mRNA mitochondria

\section{WT \\ ATP2 mRNA \\ MBS-tagged \\ ATP2 mRNA \\ + MCP-GFP-SUP35}

MBS-tagged

ATP2 mRNA

+ MCP-GFP-PAB1*

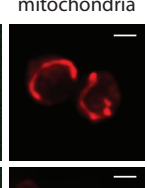

merge

B

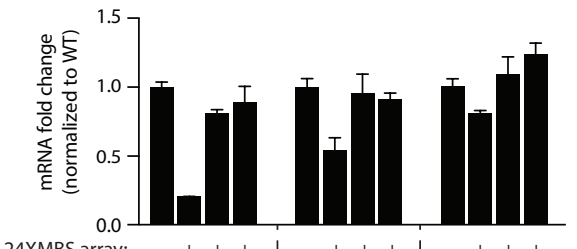

24XMBS array:

MCP-GFP:

MCP-GFP-SUP35:

MCP-GFP-PAB1*:

MBS-tagged gene:

ATP2

HAC1

PMA1

D strain background: WT $\Delta$ hac1WT WT WT WT $\Delta$ hac1WT WT WT \# of MBS on HAC1: $\quad 0 \quad 0 \quad \begin{array}{lllllllll} & 0 & 24 & 24 & 0 & 0 & 24 & 24 & 24\end{array}$ MCP-GFP:

MCP-GFP-SUP35:

MCP-GFP-PAB $1 *$

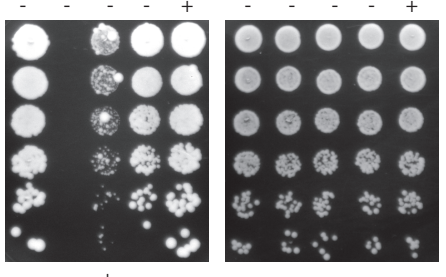

Tunicamycin

F
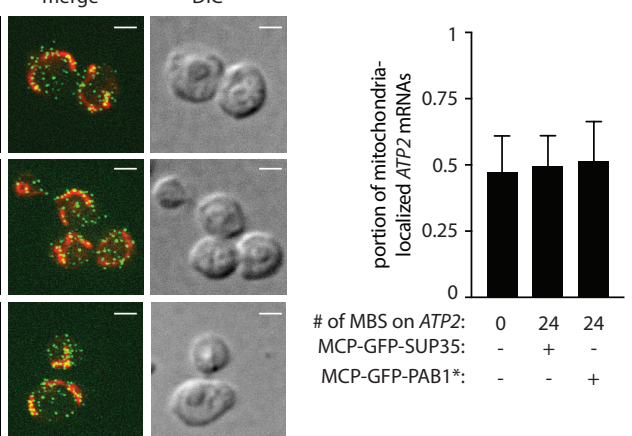

G

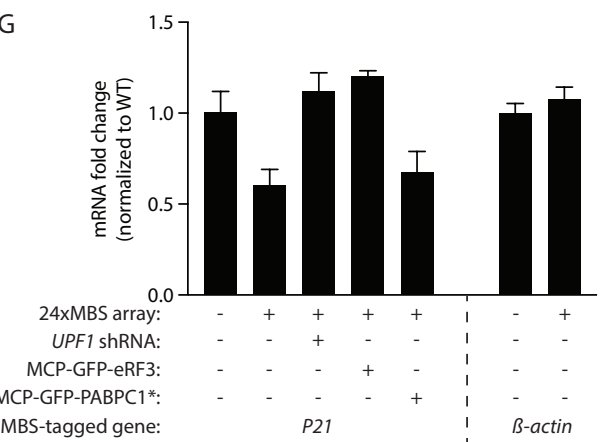

$\mathrm{H}$

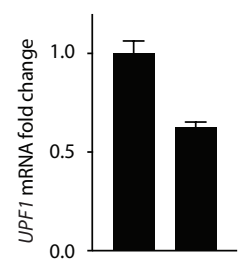

UPF1 ShRNA:

MBS-tagged gene:

P21

B-actin 
bioRxiv preprint doi: https://doi.org/10.1101/2022.02.05.479257; this version posted February 6, 2022. The copyright holder for this preprint (which was not certified by peer review) is the author/funder, who has granted bioRxiv a license to display the preprint in perpetuity. It is made available under aCC-BY-NC-ND 4.0 International license.

Supplementary Figure $1 \quad$ Li \& Maekiniemi et al

A

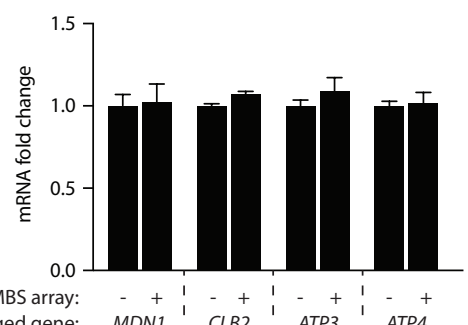

B

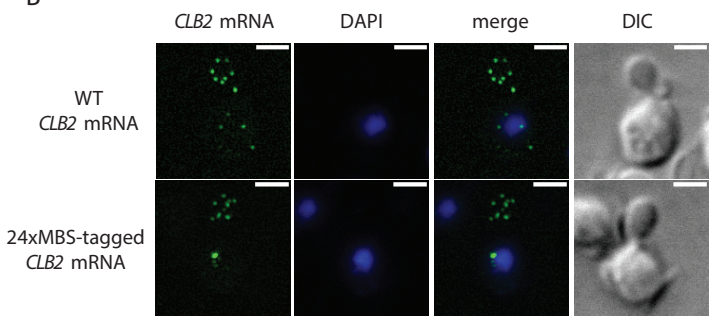

C

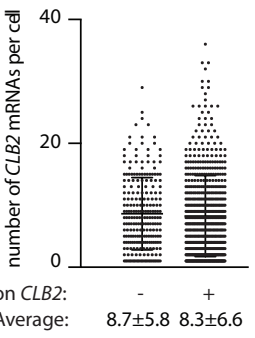


bioRxiv preprint doi: https://doi.org/10.1101/2022.02.05.479257; this version posted February 6, 2022. The copyright holder for this preprint (which was not certified by peer review) is the author/funder, who has granted bioRxiv a license to display the preprint in perpetuity. It is made available under aCC-BY-NC-ND 4.0 International license.

\section{Supplementary Figure $2 \quad$ Li \& Maekiniemi et al}

A

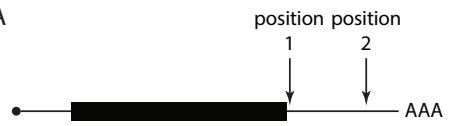

B

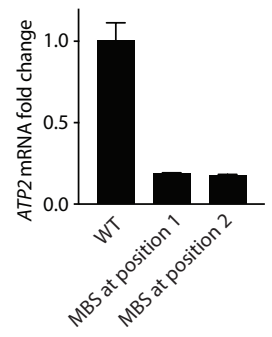


bioRxiv preprint doi: https://doi.org/10.1101/2022.02.05.479257; this version posted February 6, 2022. The copyright holder for this preprint (which was not certified by peer review) is the author/funder, who has granted bioRxiv a license to display the preprint in perpetuity. It is made available under aCC-BY-NC-ND 4.0 International license.

A MCP-GFP-PAB1

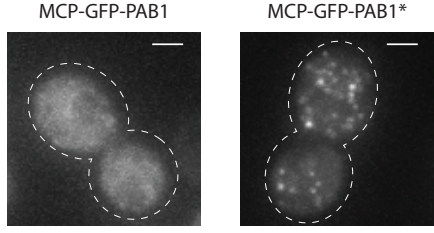

B position in human position in S. cerevisiae

mouse

human

K. lactis
S. cerevisioe

S. cerevisia
Z. rouxii

S. pombe

Y. lipolytica

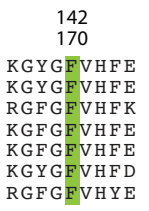

C position in human position in S. cerevisiae

mouse

human

K. lactis

S. cerevisiae

Z.rouxii

S. pombe
Y.lipolytica

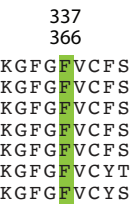


bioRxiv preprint doi: https://doi.org/10.1101/2022.02.05.479257; this version posted February 6, 2022. The copyright holder for this preprint (which was not certified by peer review) is the author/funder, who has granted bioRxiv a license to display the preprint in perpetuity. It is made available under aCC-BY-NC-ND 4.0 International license.

Supplementary Figure $4 \quad$ Li \& Maekiniemi et al

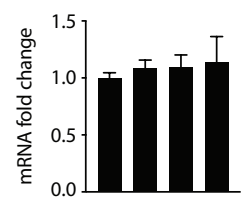

\# of MBS on ACT1: $02424 \quad 24$

MCP-GFP:

MCP-GEP-SUP35:

MCP-GFP-PAB1*: - - - + 
bioRxiv preprint doi: https://doi.org/10.1101/2022.02.05.479257; this version posted February 6, 2022. The copyright holder for this preprint (which was not certified by peer review) is the author/funder, who has granted bioRxiv a license to display the preprint in perpetuity. It is made available under aCC-BY-NC-ND 4.0 International license.

Supplementary Figure $5 \quad$ Li \& Maekiniemi et al

Representative tracks of individual ATP2 mRNAs

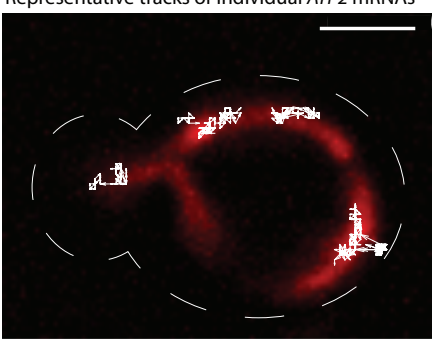


bioRxiv preprint doi: https://doi.org/10.1101/2022.02.05.479257; this version posted February 6, 2022. The copyright holder for this preprint (which was not certified by peer review) is the author/funder, who has granted bioRxiv a license to display the preprint in perpetuity. It is made available under aCC-BY-NC-ND 4.0 International license.

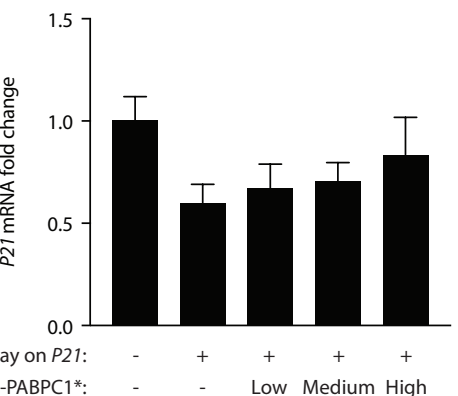

